\title{
DEVELOPMENT OF MACHINES FOR FLAMING WEED CONTROL ON HARD SURFACES
}

\author{
M. Raffaelli, L. Martelloni, C. Frasconi, M. Fontanelli, A. Peruzzi
}

\begin{abstract}
Weed control is a major issue not only in agriculture but also on hard surfaces in urban and suburban contexts. Weeds can cause serious damage to urban structures and are often considered as a sign of neglect. Moreover, citizens are becoming increasingly aware of environmental pollution and its potential risks for their health.

Flaming represents a concrete alternative to herbicide applications on hard urban surfaces. Flaming can also be a good alternative to mechanical means (e.g., string trimmers) which can seriously damage surfaces because they are too intense and in any case are often not effective. The aim of this work is to describe LPG fed flaming machines designed and built at the University of Pisa, Italy. Liquefied Petroleum Gas (LPG) is a flammable mixture of hydrocarbon gasespropane and butane. Four different machines were developed and tested in four different urban and sub-urban contexts. A small backpack flamer equipped with a manual lance was tested on a stonewall, a trolley machine with a manual lance was used to clean the base of ornamental trees, a self-propelled machine was tested in a railway station, and a mounted machine was used in a suburban cycle way. Flaming was compared to the ordinary weed control systems such as using herbicides or mowing.

The results showed that flaming can be both less expensive and more effective (on average less that $1 € m^{-2}$ year ${ }^{-1}$ maintaining weed cover below 5\% to 6\%) than the ordinary treatments in urban areas. Flaming was more effective than mowing in the suburban area but much more expensive, thus an integrated approach would be advisable in this context.

Future research should be devoted to improving the efficiency of the treatment, using for example, new burners with secondary air and precision agriculture technologies.
\end{abstract}

Keywords. Flaming machine, Physical weed control, Weed control on hard surfaces.

W eeds in urban areas can damage urban structures, making them unusable and spoiling their aesthetic qualities. Such damage is a consequence of the weed's root systems and vegetative structures. Weeds can also obstruct the urban drainage as well as spread allergenic pollen in the air thus limiting visibility (Peruzzi et al., 2010).

The use of herbicides in urban areas represents a high health risk for operators and citizens due to drifting and the presence of chemical residues. The European Union thus requires member states to ensure that the use of chemical herbicides is minimized or prohibited in public parks and gardens, sports and recreation grounds, school grounds and

Submitted for review in February 2013 as manuscript number PM 10143; approved for publication by the Power \& Machinery Division of ASABE in July 2013.

The authors are Michele Raffaelli, Professor, Luisa Martelloni, PhD Student, Marco Fontanelli, Researcher, Andrea Peruzzi, Professor. Department of Agriculture Food and Environment, University of Pisa, Pisa, Italy; Christian Frasconi, Postdoctoral Fellow. Centro di Ricerche Agro-Ambientali "Enrico Avanzi," University of Pisa, San Piero a Grado (PI), Italy. Corresponding author: Michele Raffaelli, Department of Agriculture Food and Environment, University of Pisa, Via del Borghetto, 80, 56124 Pisa, Italy; phone: 0039-050-2218947; e-mail: mraffaelli@agr.unipi.it. children's playgrounds, and in the close vicinity of healthcare facilities (OJ, 2009; Peruzzi et al., 2010).

Flame weeding is the most commonly applied nonchemical weed control on hard surfaces (Rask and Kristoffersen, 2007). The main reason for using flaming is to avoid chemical herbicides and thereby eliminate the risk of chemical residues in the environment and drinking water reservoirs. Flaming controls a wide range of annual weed species, some of which are tolerant or resistant to herbicides (Ascard, 1995).

Flaming should not be confused with burning; flaming does not burn the plants but heats them rapidly, enough to rupture the cell membranes. Flame weeding is effective due to the direct effect of the flames on the cell membranes and the indirect effect following desiccation (Ellwanger et al., 1973a, 1973b). The response to flaming varies according to species, growth stage, dose, temperature and leaf surface moisture (Ascard, 1995; Ulloa et al., 2010). Regardless of the growth stage, broadleaf weeds are more susceptible to flaming than grass species (Ulloa et al., 2010). Such differences are probably a result of the physical position of the growing point at the time of flaming (Knezevic et al., 2009). The tolerance of both grassy and broadleaf weed species increases with the increase in plant size (Parish, 1990; Ulloa et al., 2010). 
Plant survival after flaming is largely dependent on the plant's ability to regrow after flaming, in general the annual broadleaf desiccates completely a few days after treatment, whereas the grassy species grows new leaves after a week or two (Ulloa et al., 2010).

The most important factor distinguishing sensitive and tolerant species is not heat tolerance, but rather the ability of plants to regrow after the flame treatment. The larger amount of reserve food in the roots increases the plant's ability to regrow (Ascard, 1995).

Research groups worldwide have used different types of flaming equipment and several burner types for flaming. Holmøy and Storeheier (1995) indicate that tubular burners producing long narrow flames are suitable for non-selective flaming using covered flamers. Kristoffersen et al. (2008) used a hand-pushed $50 \mathrm{~cm}$ wide infrared gas-burner (HOAF Infrared Technology; NL-7575 ED Oldenzaal, Netherlands) for flame weeding on traffic islands. Rask et al. (2012) used a $75 \mathrm{~cm}$ wide infrared gas-burner (HOAF Infrared Technology; NL-7575 ED Oldenzaal, Netherlands) mounted on a self-driven machine for flame weeding on flagstones. Ulloa et al. (2010) used the propane flamer "LT $2 \times 8$ Liquid Torch" (Flame Engineering Inc., La Crosse, Kan.) to test the tolerance of selected weed species to broadcast flaming at different growth stages. However, the flaming machines and the burners used in these experiments, as well as those available on the market, are often not suitable and efficient for treatments in different urban areas.

The aim of this work is to describe flaming machines designed and built at the University of Pisa, which are suitable for weed control treatments on different types of hard surfaces in urban areas. Their performance in controlling weeds on different hard surfaces in urban areas is reported.

\section{Materials AND Methods}

\section{DESCRIPTION OF THE MACHINES}

Four prototypes of flaming machines were designed and built at the workshops of the Department of Agriculture, Food and Environment of the University of Pisa $\left(+43.7^{\circ} \mathrm{N}\right.$ $+10.3^{\circ} \mathrm{E}$ ) in $2006-2007$ for weed control on different types of hard surfaces in urban and sub-urban areas. The prototypes are: a backpack flamer, a trolley flaming machine, a self-propelled flaming machine, and a mounted flaming machine. They differ considerably in their mode of use, their suitability for different kinds of hard surfaces, and their performance. The machines have a common system for controlling weeds, i.e. the high temperature flame generated by Liquefied Petroleum Gas (LPG) which heats weed leaves extremely rapidly and kills them. All the machines (table 1) are equipped with rectangular-shaped open flat burners fed by LPG which is a flammable mixture of propane and butane.

\section{Backpack Flamer}

The backpack flamer (fig. 1) is suitable for small surfaces and steep areas. It is equipped with a slot for a LPG tank, a manual lance with an ergonomic handle, a
Table 1. Specifications and capacities of the machines designed and built by the University of Pisa for weed control on hard surfaces in urban and suburban areas.

\begin{tabular}{|c|c|c|c|}
\hline Characteristics & $\begin{array}{c}\text { Backpack } \\
\text { Flamer and } \\
\text { Trolley Flaming } \\
\text { Machine }\end{array}$ & $\begin{array}{c}\text { Self-Propelled } \\
\text { Flaming } \\
\text { Machine } \\
\end{array}$ & $\begin{array}{l}\text { Mounted } \\
\text { Flaming } \\
\text { Machine }\end{array}$ \\
\hline Burner width (cm) & 15 & 25 & 50 \\
\hline Number of burners $\left(n^{\circ}\right)$ & 1 & 5 & 4 \\
\hline Total working width $(\mathrm{cm})$ & 15 & 125 & 200 \\
\hline Maximum speed $\left(\mathrm{km} \mathrm{h}^{-1}\right)$ & (walking speed) & 5 & (tractor speed) \\
\hline $\begin{array}{l}\text { Ordinary working speed } \\
\left(\mathrm{km} \mathrm{h}^{-1}\right)\end{array}$ & $1-2$ & $1-3$ & $2-7$ \\
\hline $\begin{array}{l}\text { Theoretical working } \\
\text { capacity }\left(\mathrm{m}^{2} \mathrm{~h}^{-1}\right)\end{array}$ & $150-300$ & $1250-3750$ & $4000-14000$ \\
\hline
\end{tabular}

pressure regulator and a pressure gauge, maximum and minimum regulator taps, a trigger for LPG supply, and a $15 \mathrm{~cm}$ rod-shaped open-flame burner equipped with an external nozzle with a diameter of $0.7 \mathrm{~mm}$. The base of the backpack was a backpack for a trimmer, which was modified for an LPG tank. The whole mass of the LPG cylinder is $11 \mathrm{~kg}$ ( $5 \mathrm{~kg}$ of LPG plus $6 \mathrm{~kg}$ of the empty steel tank), by itself the backpack weighs $3.5 \mathrm{~kg}$. The manual lance has a shoulder strap and an ergonomic cross handle. The gas pipe is $1.5 \mathrm{~m}$ long.

\section{Trolley Flaming Machine}

The trolley flaming machine has the same manual lance as the backpack flamer, but is equipped with pneumatic wheels in order to easily carry a $15 \mathrm{~kg}$ LPG tank (gross weight of about $30 \mathrm{~kg}$ ) (fig. 2). The trolley is lightweight $(11 \mathrm{~kg})$ and can be easily folded for transport. The gas pipe is $5 \mathrm{~m}$ long in order to give the operator the opportunity to cover a wide area without moving the trolley from a fixed position.

\section{Self-Propelled Flaming Machine}

The self-propelled flaming machine is driven by a walking operator and equipped with four wheels (with two front drive wheels) and a $4.4 \mathrm{~kW}$ four-stroke gasoline engine, with a 5 forward and 1 reverse speed gear (fig. 3). It is built on the base of a self-propelled wheel barrow. The forward speed ranges from 1 up to $5 \mathrm{~km} \mathrm{~h}^{-1}$. The net weight of the machine is $139 \mathrm{~kg}$ and it is $140 \mathrm{~cm}$ long, $103 \mathrm{~cm}$ high, and from 95 to $140 \mathrm{~cm}$ wide (varying with the

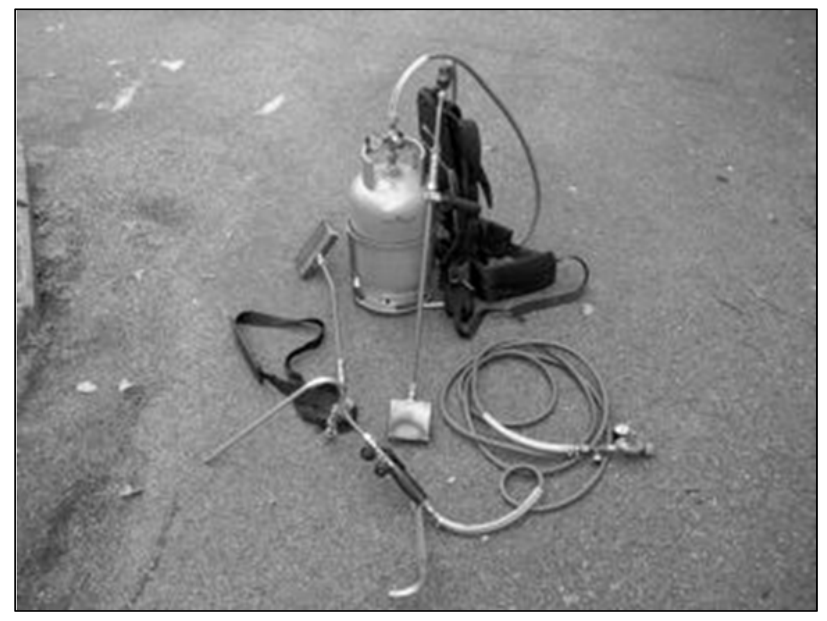

Figure 1. Backpack flamer with two different manual lances. 

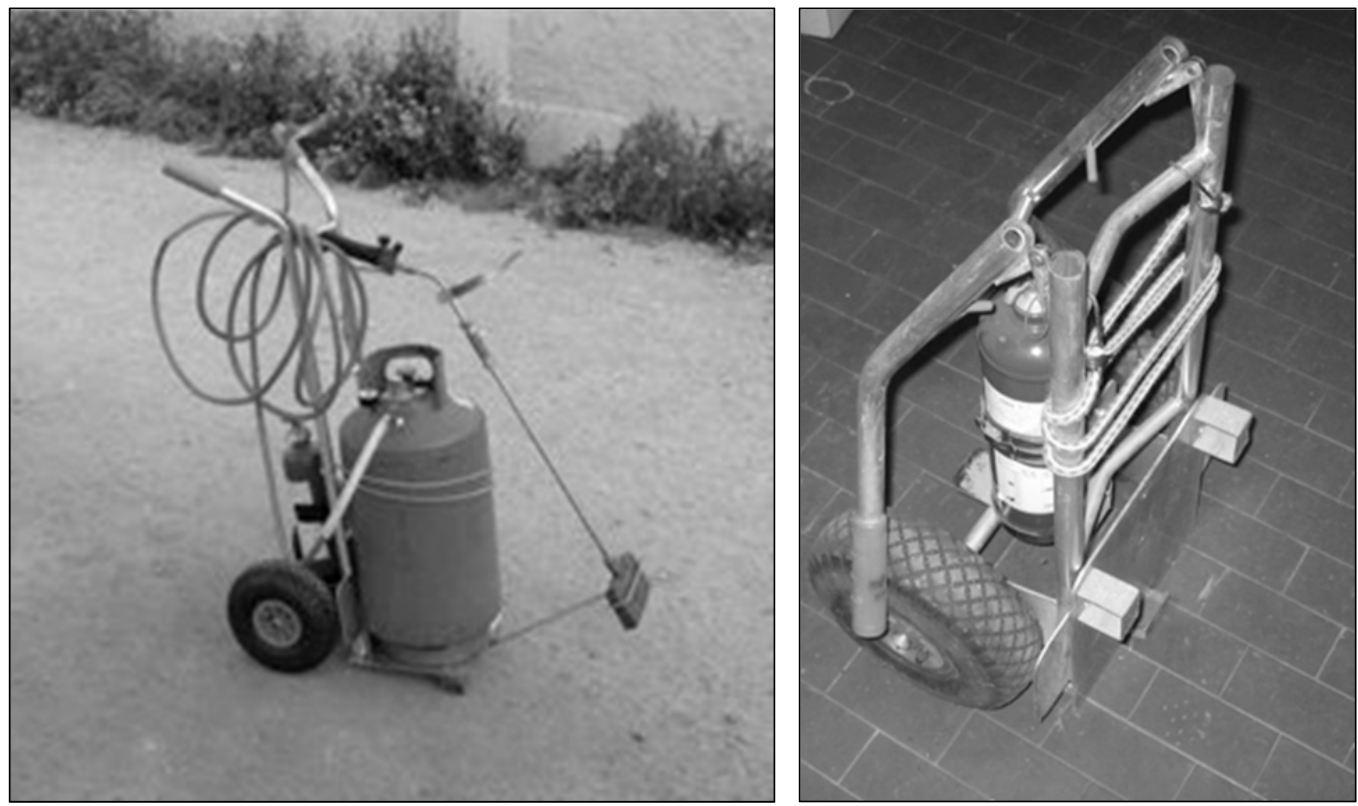

Figure 2. Trolley flaming machine.

adjustment). The flaming machine is equipped with five $25 \mathrm{~cm}$ wide rod burners with an external nozzle $(\varnothing 1.1 \mathrm{~mm})$, placed in front of a small frame, and a hand lance with a $15 \mathrm{~cm}$ wide rod burner with an external nozzle $(\varnothing 0.7 \mathrm{~mm})$.

By varying the inclination of the lateral parts of the frame with respect to the driving direction, the two side burners can be easily adjusted for frontal or side treatments (fig. 4). The two lateral parts of the small frame are connected to the central part by elastic saloon-door hinges to avoid damage due to bumps (fig. 4). All the burners can be easily adjusted by varying the height and inclination with respect to the soil surface. Normally the burners are set at a height of $7 \mathrm{~cm}$ at an angle of $30^{\circ}$ to $45^{\circ}$ to the ground, a setting that guarantees the maximum effectiveness on weeds. The hand lance is equipped with an $8 \mathrm{~m}$ long gas tube which is reeled by an automatic cable reel that has been modified to work specifically with LPG gas. The machine is equipped with a heat exchange system. Two LPG tanks are placed inside a hopper that contains water. The water is heated by means of the exhaust which passes through a copper tube placed inside the hopper; this solution allows a good heat exchange, thus recovering energy (fig. 4).

All the LPG tanks are equipped with a pressure regulator and a manometer and are connected to a control system. The control system of each burner consists of two manual valves plus an automatic safety valve. The manual valves allow the LPG feed to be adjusted (close, high or low). The
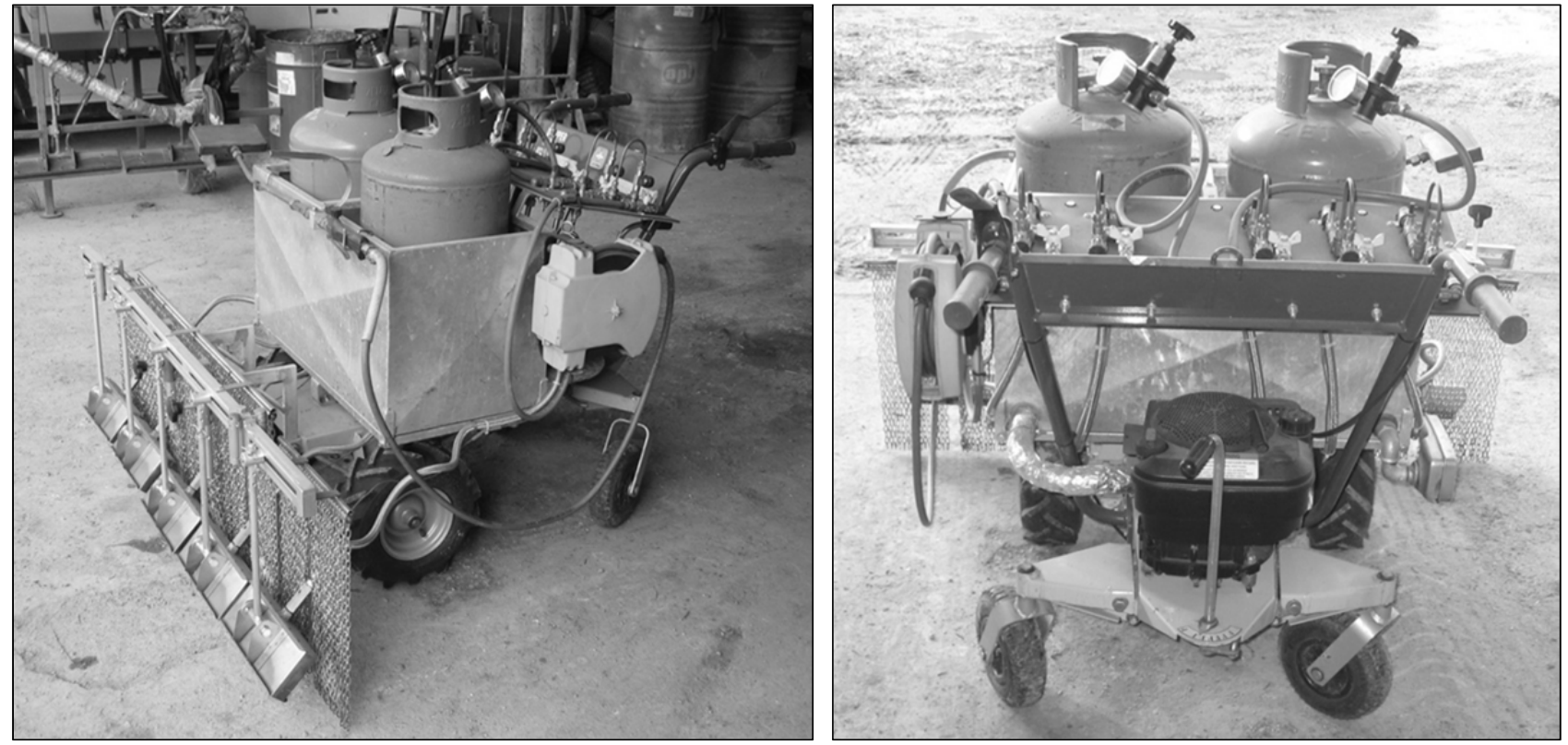

Figure 3. Self-propelled flaming machine. 

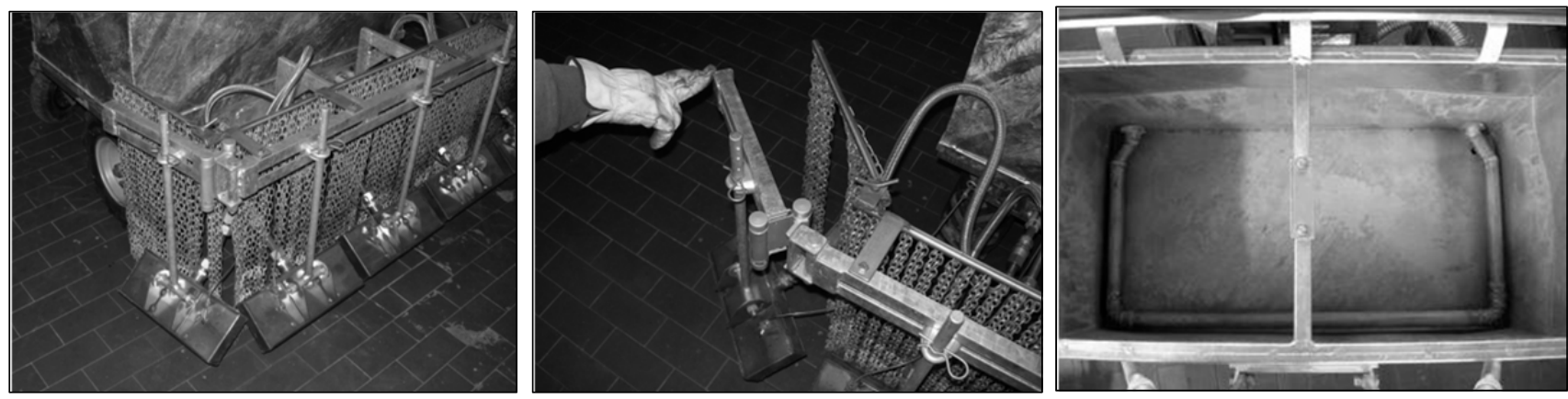

Figure 4. Side burners adjusted for side treatments (left), lateral parts of the frame connected with elastic hinges (middle) and heat exchanger (right).

automatic safety valve is connected to a thermocouple located inside the burner, which closes the LPG feed if the flame shuts down. All the controls are in front of the operator and are easily adjustable.

\section{Mounted Flaming Machine}

The mounted flaming machine can be equipped with four commercial LPG tanks (both 15 and $25 \mathrm{~kg}$ ), reaching a total LPG capacity of 60 or $100 \mathrm{~kg}$. It can be coupled to a common tractor by the three-point hitch (fig. 5). Four $50 \mathrm{~cm}$ wide rod burners with an external nozzle $(\varnothing 1.3 \mathrm{~mm})$ provide a working width of $2 \mathrm{~m}$. All the burners can be easily adjusted by varying the height and inclination with respect to the soil surface. Normally the burners are set at a height of 7 to $10 \mathrm{~cm}$ at an angle of $30^{\circ}$ to $45^{\circ}$ to the ground, a setting that guarantees the maximum effectiveness on weeds. The right height of the burners from the soil is provided by articulated parallelograms. The net weight of the machine is about $270 \mathrm{~kg}$ and was designed for both agricultural and urban/suburban treatments in wide areas. The LPG system is the same as described for the self-propelled machine, but the maximum/minimum valves are electronically controlled by a specific panel which can be placed in the cabin of the tractor. The panel is very simple and has one switch (on=working pressure; off=pilot flame) and two different light controls (green/red=burner on/off; light on/off=working pressure/pilot flame). Again, the position

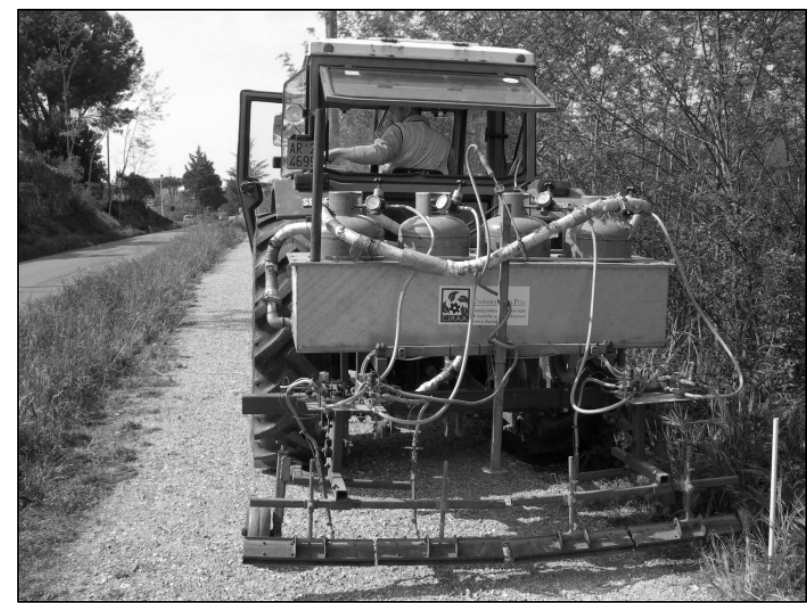

Figure 5. Mounted flaming machine, equipped with four $50 \mathrm{~cm}$ wide rod burners. of the burners can be adjusted to different requirements. The machine is modular and the burner type and working width can be easily changed.

\section{Specifications of the Burners and the LPG Feeding System}

The burners are made from stainless steel and characterized by an external carter and an internal pierced-rod (fig. 6). The holes are placed $3.5 \mathrm{~cm}$ apart and have a diameter of $2.5 \mathrm{~mm}$. The external width of the burners varies from 10 to $50 \mathrm{~cm}$ depending on the different types of machines. These burners work with pre-mixed gas. A brass external mixer, based on the Venturi effect, provides the right ratio between air and gas (fig. 6).

The depression is created by the flow of LPG at high speed achieved by a passage through a narrow nozzle section (fig. 6). The diameter of the nozzle varies from 0.7 to $1.3 \mathrm{~mm}$, according to the different external width. The temperature of the flame is measured with an $\mathrm{R}$ thermocouple in the center of the burner at a distance of $5 \mathrm{~cm}$ from the carter, and varies from $1400^{\circ} \mathrm{C}$ to $1500^{\circ} \mathrm{C}$ depending on the burner width, the nozzle diameter and the working pressure. The same parameters are strictly related to gas consumption, which ranges from about 1 to $5 \mathrm{~kg} \mathrm{~h}^{-1}$. These burners produce a flat, wide, and stable flame (fig. 7).

The working pressure of these burners usually varies from 0.2 to $0.4 \mathrm{MPa}$. The pressure increase leads to a longer flame (and consequently at the same working speed, a longer exposure time). The lowest pressure $(0.2 \mathrm{MPa})$ is commonly used for slow treatments (in general with manual equipment) or in the case of low weed infestation. A pressure increase is usually required with faster treatments and/or high weed infestation. Table 2 shows the main characteristics of the burners provided on the prototypes.

The machines are equipped with commercial cylindrical Italian LPG tanks, and the gas content ranges from 3 to $25 \mathrm{~kg}$ each. One pressure gauge with a pressure regulator per tank is provided, in order to adjust the gas flow. A maximum/minimum valve reduces the working flame to a small pilot light when the treatment needs to be stopped temporarily, for instance when the operator has to walk from one site to another or while turning the machine. The pilot flame pressure can be adjusted by another specific regulator. The self-propelled and the mounted machines are 

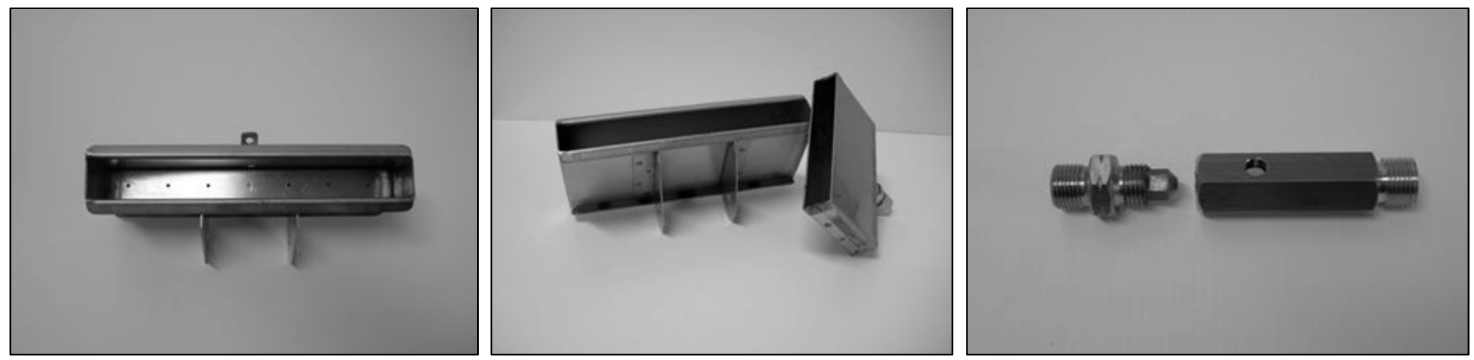

Figure 6. Burners (left-center) and the external mixer with the nozzle (right).

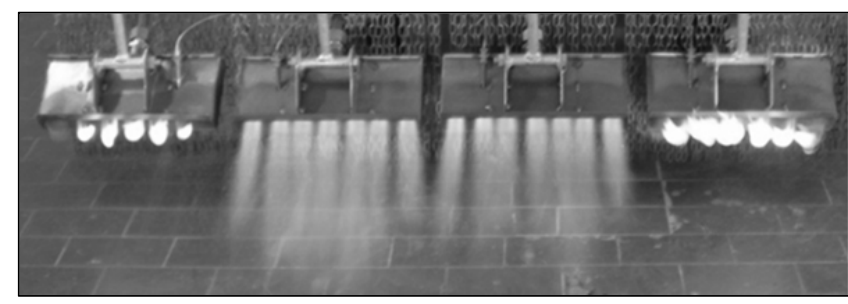

Figure 7. Working burners and pilot flame.

equipped with a specific safety automated electro-valve, connected to a thermocouple, which stops the gas flow if the flame in the burner accidentally shuts down. The change of state of the LPG, from liquid to gas, requires energy, which causes the tank to cool, if the rate of vaporization is higher than the heat transferred from the outside to the tank walls. During treatment, if the cooling drops below the temperature of LPG vaporization, the working pressure falls to 0 and the gas stops flowing. To overcome this, the self-propelled and the mounted machines are equipped with a heat exchange system, which collects the exhaust from the endothermic engine in a serpentine pipe inside a hopper containing water and the LPG tanks. The heat from the exhaust is transferred to the water and then to the LPG tank.

Obviously this solution is not required for the equipment without an internal combustion engine. When no heat exchange system is required, the duration of the tank depends on the external temperature, on the volume of the tank itself, and on the gas flow. The higher the demand is for gas by the burner, the lower the duration of the tank before cooling. The higher the tank content, the higher the duration of the tank before cooling. For example, in the case of a manual treatment with a backpack machine and a small tank containing $5 \mathrm{~kg}$ of LPG, with a working pressure of $0.2 \mathrm{MPa}$ and an external temperature of about $20^{\circ} \mathrm{C}$, the duration is about $2 \mathrm{~h}$. After this time the tank needs to be replaced. It can be used again when it is warmer.

\section{The EXPERIMENTAL TRIALS}

The flaming machine prototypes were tested on different kinds of hard surfaces in order to test their effectiveness. Experimental designs were a randomized block with four replications. The flaming consisted in repeated applications (minimum four treatments year ${ }^{-1}$ ). The number of repeated treatments was decided year-by-year by taking into account the real need for weed control determined by the percentage of weed cover. The LPG consumption necessary to control weeds varies considerably depending on the species and development stage, as well as the required control effect.

LPG consumption was calculated by repeatedly weighing the propane tanks before and after each treatment. The working time for each treatment was measured with a digital chronometer.

Weed cover percentage was rated visually at the beginning of the trials and periodically during the experimental period. The percentage weed cover was evaluated within a frame of $50 \times 50 \mathrm{~cm}$, and was subjected to standard ANOVA. Fisher's Protected LSD test was used with $\alpha=0.05$ to describe differences between means. CoStat software was used (CoHort Software, 1998-2008). Square root transformation was applied to weed cover data before ANOVA.

Total machines cost per use was calculated by taking into account the standard methodology suggested in three principal texts on agricultural machinery and farm mechanization (Biondi, 1999; Hunt, 2001; Lazzari and Mazzetto, 2005). Machinery system costs were calculated by summing fixed and variable costs. The rates of depreciation of the flaming machine were calculated considering the purchase price of new machines (595€ backpack flamer, $770 €$ trolley flaming machine, $3440 €$ self-propelled flaming machine, and $7000 €$ mounted flaming machine). The prices are those set by the MAITO (MAITO, 2013), which since 2012 have been selling machines based on the prototypes designed and built at the University of Pisa. The purchase price of the tractor

Table 2. Main characteristics of the different liquefied petroleum gas (LPG) fed burners, which the machines designed and built by the University of Pisa are equipped with, for weed control on hard surfaces in urban and suburban areas.

\begin{tabular}{|c|c|c|c|c|c|c|c|c|c|}
\hline \multirow{2}{*}{$\frac{\text { Characteristics }}{\text { Burner width }(\mathrm{cm})}$} & \multicolumn{3}{|c|}{$\begin{array}{c}\text { Backpack Flamer and } \\
\text { Trolley Flaming Machine }\end{array}$} & \multicolumn{3}{|c|}{$\begin{array}{c}\text { Self-Propelled } \\
\text { Flaming Machine } \\
\end{array}$} & \multicolumn{3}{|c|}{$\begin{array}{c}\text { Mounted } \\
\text { Flaming Machine } \\
\end{array}$} \\
\hline & & 15 & & & 25 & & & 50 & \\
\hline Nozzle diameter (mm) & & 0.7 & & & 1.1 & & & 1.3 & \\
\hline LPG pressure $(\mathrm{MPa})$ & 0.2 & 0.3 & 0.4 & 0.2 & 0.3 & 0.4 & 0.2 & 0.3 & 0.4 \\
\hline LPG consumption $\left(\mathrm{kg} \mathrm{h}^{-1}\right)$ & 1.2 & 1.6 & 2.1 & 2.8 & 3.7 & 4.7 & 3.9 & 5.2 & 6.5 \\
\hline Flame temperature $\left({ }^{\circ} \mathrm{C}\right)^{[\mathrm{a}]}$ & 1476 & 1518 & 1520 & 1470 & 1490 & 1486 & 1410 & 1450 & 1460 \\
\hline
\end{tabular}

[a] Measured with an $\mathrm{R}$ thermocouple at a distance of $5 \mathrm{~cm}$ from the carter of the burner. 
(26 kW) coupled with the mounted flaming machine was $21900 €$.

The economic life was 12 years for the tractor, 10 years for the backpack flamer and the trolley flaming machine, and 8 years for the self-propelled flaming machine and the mounted flaming machine. The factor for repair and maintenance was $75 \%$.

The labor costs were $15 € \mathrm{~h}^{-1}$ for the tractor driver, and $13 € \mathrm{~h}^{-1}$ for the other workers. The LPG cost $2.1 €$ per kg.

The costs for the management systems compared with flaming are those shown in the price list of agricultural operations in Italy (F.R.I.M.A.T., 2012).

\section{Backpack Flamer}

The experiment was carried out in an urban area in the municipality of San Giuliano Terme (Pisa, Italy, $+43^{\circ} 47^{\prime} \mathrm{N}$ $+10^{\circ} 25^{\prime}$ E) from May 2009 to May 2011.

The backpack flamer was tested on a stonewall area of $32 \mathrm{~m}^{2}$ infested with Parietaria officinalis L. The vertical surface characterizing the wall was suitable for the use of the backpack equipment (fig. 8).

The weed management systems compared were flaming, mowing and the untreated control. The aim was to maintain the threshold level of weed cover at under 5\%. Yearly mowing management includes mowing twice with a standard string trimmer (in May and October), blowing and collecting the cut weeds and transporting them to a dump. These are the usual weed control procedures adopted by the municipality, and are all included in the working times and total costs reported in the results.

\section{Trolley Flaming Machine}

The experiment was carried out in an urban area of Livorno, Italy $\left(+43^{\circ} 31^{\prime} \mathrm{N}+10^{\circ} 18^{\prime} \mathrm{E}\right.$ ) from April 2006 to June 2008.

The trolley machine was tested on cement areas of $2.9 \mathrm{~m}^{2}(1.6 \times 1.8 \mathrm{~m})$ each, placed around an ornamental tree Tamerix gallica L. and characterized by several little holes for irrigation-rainfall purposes (fig. 9). To maintain the pleasant appearance, chemical herbicides are generally used on the weeds in and around the little holes and the non-cemented area where Tamerix gallica grows.

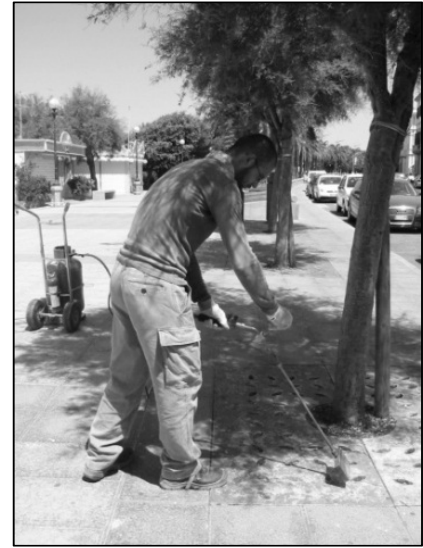

(a)

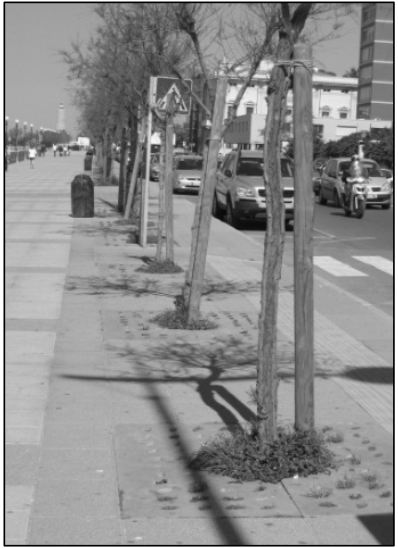

(b)
Figure 9. Trolley flaming machine at work (a) and an overview of the treated avenue (b).

The weed management systems compared were low frequency flaming, high frequency flaming, chemical herbicides, and the untreated control.

The herbicide was distributed with a manual lance connected to a mounted sprayer. Two chemical herbicide treatments were performed each year (a.i. glyphosate, dose $1.1 \mathrm{~g} \mathrm{~m}^{-2}$ ). Two treatments per year is the maximum number of chemical herbicide applications permitted by the local authorities. In addition to herbicide distribution, chemical management includes mowing the dried weeds, blowing the cut weeds, and transporting them to the dump. As with the backpack system, these steps are all included in the working times and total costs reported in the results.

The number of high frequency treatments was established in order guarantee a constant level of percentage weed cover not greater than $10 \%$ throughout the whole experimental period. A weed cover of $10 \%$ represents the threshold accepted by the local authorities in areas of high urban importance. The number of low frequency treatments was established as about half that of the high frequency in order to verify the level of effectiveness of a lower number of treatments.

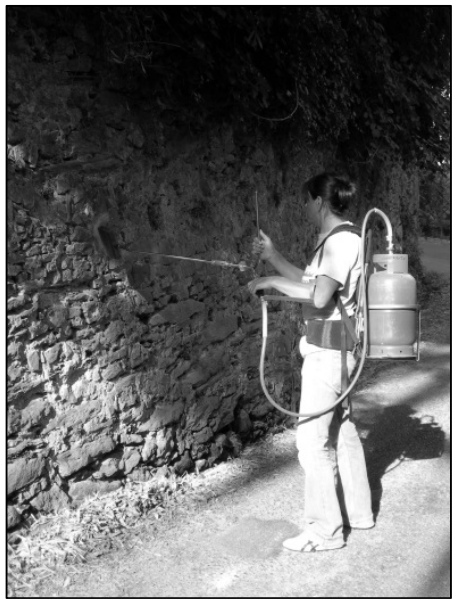

(a)

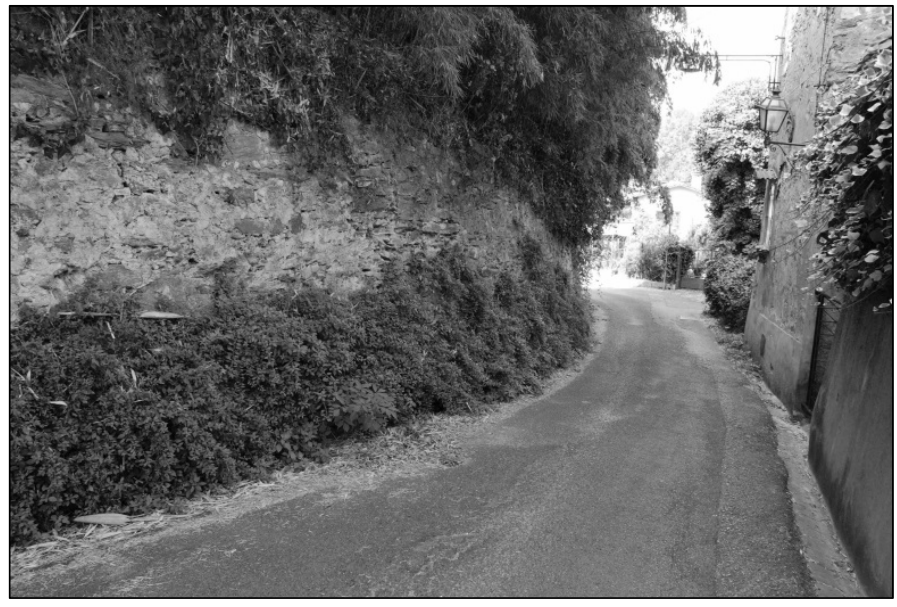

(b)

Figure 8. Backpack flamer at work (a) and the stonewall (b). 


\section{Self-Propelled Flaming Machine}

The experiment was carried out at the railway station of San Giuliano Terme (Pisa, Italy, $+43^{\circ} 45^{\prime} \mathrm{N}+10^{\circ} 26^{\prime} \mathrm{E}$ ) from May 2009 to May 2011. The self-propelled machine was tested on a tiled cement area of $328 \mathrm{~m}^{2}$ infested with weeds between the tiles (fig. 10). The weed management systems compared were flaming, mowing, and the untreated control. The aim was to maintain the threshold level of percentage weed cover under the $5 \%$. The yearly mowing management is as outlined for the previous cases, and the working times and total costs reported in the results.

\section{Mounted Flaming Machine}

The experiment was carried out in a suburban area of Arezzo (Italy, $+43^{\circ} 27^{\prime} \mathrm{N}+11^{\circ} 49^{\prime} \mathrm{E}$ ) during a growing cycle in 2011.

The mounted flaming machine was tested on a graveled cycle way area of $1470 \mathrm{~m}^{2}$ (fig. 11). In this study a randomized block was used with six replications, because of the weed cover variability observed along the cycle way (490 m long).

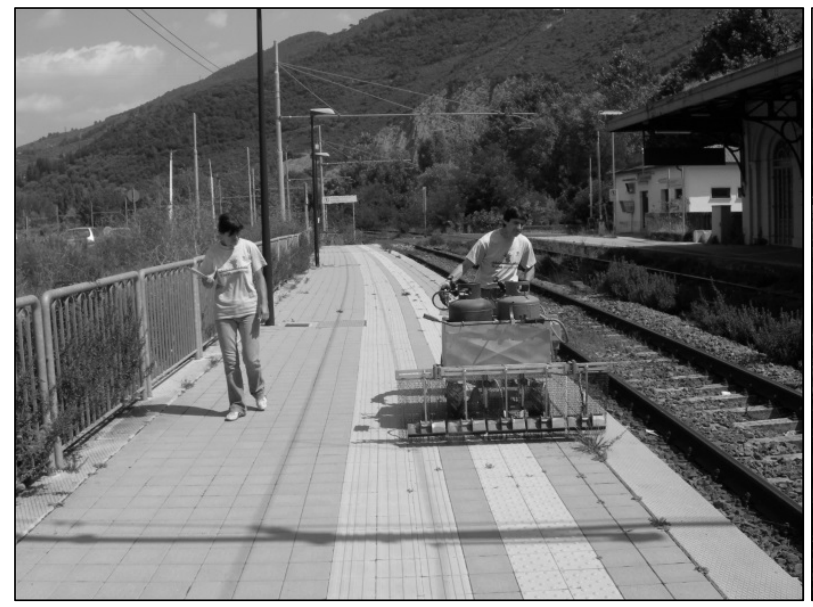

(a)
The weed management systems compared were flaming, mowing and the untreated control. The yearly mowing was performed four times with a mounted mowing shredder.

The aim was to maintain the threshold level of weed cover under $20 \%$, higher than the other experiments but accepted because it was a suburban area.

\section{RESULTS AND DISCUSSION \\ BACKPACK FLAMER}

Initial weed composition was entirely represented by Parietaria officinalis L., which remained the only species infesting the stonewall throughout the whole experimental period. Nine flaming treatments were performed during the first year and eight in the second year (table 3). The experiment started in May 2009 after mowing the whole wall so that the initial weed cover for all the plots was about $10 \%$. After two months and two flaming treatments the weed cover in the flaming blocks was $3 \%$, whereas for mowing plots (not treated in this period of time) it was $70 \%$.

Figure 10. Self-propelled flaming machine at work (a) and the railway station (b).

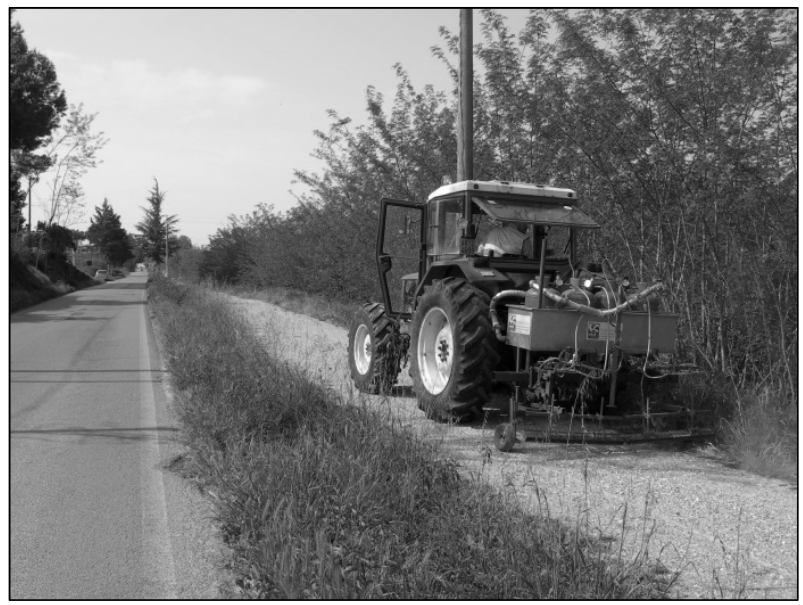

(a)

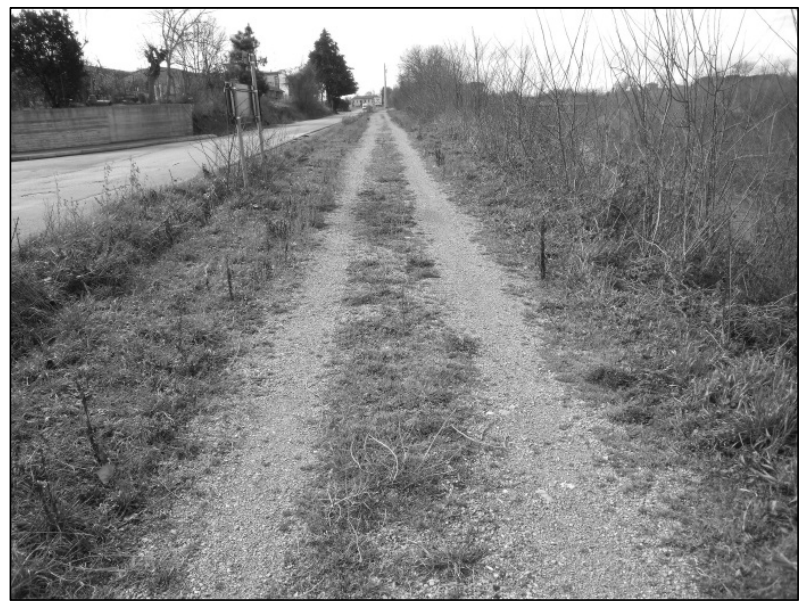

(b)

Figure 11. Mounted flaming machine at work (a) and an overview of the gravelled cycleway. 
Table 3. Mean weed cover and yearly number of treatments, LPG consumption, working time, and total cost for different weed control systems on the stonewall during the two years of trial (from May 2009 to May 2011 ).

\begin{tabular}{|c|c|c|c|c|c|}
\hline & \multicolumn{2}{|c|}{$\begin{array}{c}\text { Flaming } \\
\text { Backpack Flamer }\end{array}$} & \multicolumn{2}{|c|}{$\begin{array}{c}\text { Mowing } \\
\text { String Trimmer }\end{array}$} & \multirow{2}{*}{ Control } \\
\hline & First Year & Second Year & First Year & Second Year & \\
\hline Yearly number of treatments & 9 & 8 & 2 & 2 & 0 \\
\hline Weed cover mean $(\%)$ & \multicolumn{2}{|c|}{$0.4 \mathrm{c}$} & \multicolumn{2}{|c|}{$55.8 \mathrm{~b}$} & $89.4 \mathrm{a}$ \\
\hline Yearly LPG consumption $\left(\mathrm{kg} \mathrm{m}^{-2}\right)$ & 0.053 & 0.050 & - & - & \\
\hline Yearly working time $\left(\mathrm{h} \mathrm{m}^{-2}\right)$ & 0.044 & 0.041 & 0.015 & 0.015 & \\
\hline Yearly total cost per use $\left(€ \mathrm{~m}^{-2}\right)$ & 0.96 & 0.90 & 1.25 & 1.25 & \\
\hline
\end{tabular}

There were statistical differences in the means of weed cover percentage over the two-year experimental period due to the different weed control systems (table 3). Flaming enabled a constant weed cover of $0.4 \%$ to be maintained. With mowing, the weed cover was on average $56 \%$ (with peaks of $70 \%$ to $90 \%$ between the treatments). Sixteen months after the beginning of the trial, the untreated control had $100 \%$ weed cover.

LPG working pressure was $0.2 \mathrm{MPa}$. The mean LPG consumption for a single treatment was $0.005 \mathrm{~kg} \mathrm{~m}^{-2}$. The yearly LPG consumption for the first year for controlling Parietaria officinalis L. was about the same as the second year $\left(0.05 \mathrm{~kg} \mathrm{~m}^{-2}\right)$ : the number of treatments only differed by one and the yearly working time for treatments was about the same each year $\left(0.04 \mathrm{~h} \mathrm{~m}^{-2}\right)$ (table 3$)$. Mowing time was $0.015 \mathrm{~h} \mathrm{~m}^{-2}$.

Kristoffersen et al. (2008) flamed the kerb stones of traffic islands eight times during the growing season with a hand-pushed $50 \mathrm{~cm}$ wide infrared gas-burner, for a LPG consumption of $0.12 \mathrm{~kg} \mathrm{~m}^{-2}$ per year, and obtained a reduction in the percentage of weed cover of $81 \%$ compared to the untreated control.

In our study, the total cost for mowing (yearly costs for mowing plus blow cut weeds and transport to the dump) was $1.25 € \mathrm{~m}^{-2}$ each year. Total cost for flaming was $0.96 €$ $\mathrm{m}^{-2}$ the first year and $0.90 € \mathrm{~m}^{-2}$ the second year (table 3 ). Yearly flaming was more economical than mowing and succeeded in maintaining the threshold level of weed cover under $5 \%$.

\section{Trolley Flaming Machine}

Initial weed composition was mainly represented by Spergularia spp., Sonchus spp., Hordeum, spp. and Herniaria spp. Weed cover before treatments was about $50 \%$.

The number of treatments in high frequency flaming was 12 the first year and 7 the second year; 7 the first year and 4 the second year in low frequency. The number of flaming treatments, deemed necessary to maintain the threshold level of weed cover under $10 \%$, in the first year was higher than in the second year, because weed density was lower as a consequence of the depletion of root reserves due to the first-year flaming treatments on perennial weeds.

Hansen et al. (2004) found that 11 to 12 treatments per growing season were necessary to achieve acceptable weed control on areas heavily infested with perennial weeds. Our results demonstrated that the number of flaming treatments in a permanent urban area could be reduced in the course of time because after treatment, weed roots deplete their food storage and cannot regrow. A new infestation by weed seeds is simple to control because the seedlings are killed and the energy store contained in the seeds is very low and does not permit regrowth. Both high and low frequencies were able to guarantee a constant mean of the percentage of weed cover under $10 \%$ of the threshold throughout the whole experimental period (table 4). In addition there were no statistical differences between the flaming plots, probably because the weed regrowth in this area was not enough to require a high number of treatments. Chemical herbicides resulted in a mean of weed cover of about $15 \%$ (table 4); with peaks higher than $20 \%$ from March to June 2007, demonstrating that two treatments are not sufficient to maintain the threshold level of weed cover under $10 \%$. The mean weed cover in the untreated control was about $40 \%$ throughout the two-year experiment (table 4).

In flaming plots, Spergularia spp. (Spergularia spp. can be woody at the base, and thus be resistant to flaming) and graminaceous species represented 5\% of the weed cover at the end of the experimental period.

An experiment on a surface with holes was conducted by Rask et al. (2012) who used flaming treatments once or twice on a flagstone area of $24 \mathrm{~m}^{2}$ where annual bluegrass and perennial ryegrass had been transplanted in the flagstone holes. In Rask's case, the LPG consumption was $0.008 \mathrm{~kg} \mathrm{~m}^{-2}$ for each treatment. Thirty-five days after the first flaming, the aboveground biomass of ryegrass was on average $48 \%$ of control plants. Aboveground biomass of perennial ryegrass flamed twice was about $16 \%$ lower than plants flamed once.

LPG working pressure was $0.2 \mathrm{MPa}$. The LPG consumption for a single treatment was $0.005 \mathrm{~kg} \mathrm{~m}^{-2}$. The

Table 4. Mean weed cover and yearly number of treatments, LPG consumption, working time and total cost for different weed control systems on cement surfaces with holes during the two year of trial (from April 2006 to June 2008).

\begin{tabular}{|c|c|c|c|c|c|c|c|}
\hline & \multicolumn{2}{|c|}{$\begin{array}{l}\text { Flaming High Frequency } \\
\text { Trolley Flaming Machine }\end{array}$} & \multicolumn{2}{|c|}{$\begin{array}{l}\text { Flaming Low Frequency } \\
\text { Trolley Flaming Machine }\end{array}$} & \multicolumn{2}{|c|}{$\begin{array}{c}\text { Herbicide } \\
\text { Spryer With Manual Lance }\end{array}$} & \multirow{2}{*}{$\begin{array}{c}\text { Control } \\
-\end{array}$} \\
\hline & First Year & Second Year & First Year & Second Year & First Year & Second Year & \\
\hline Yearly number of treatments & 12 & 7 & 7 & 4 & 2 & 2 & 0 \\
\hline Weed cover mean $(\%)$ & \multicolumn{2}{|c|}{$5.4 \mathrm{c}$} & \multicolumn{2}{|c|}{$6.3 \mathrm{c}$} & \multicolumn{2}{|c|}{$14.7 \mathrm{~b}$} & $37.6 \mathrm{a}$ \\
\hline Yearly LPG consumption $\left(\mathrm{kg} \mathrm{m}^{-2}\right)$ & 0.066 & 0.035 & 0.040 & 0.020 & - & - & \\
\hline Yearly working time $\left(\mathrm{h} \mathrm{m}^{-2}\right)$ & 0.055 & 0.029 & 0.033 & 0.017 & 0.012 & 0.012 & \\
\hline Yearly total cost per use $\left(€ \mathrm{~m}^{-2}\right)$ & 1.19 & 0.61 & 0.72 & 0.38 & 1.54 & 1.54 & \\
\hline
\end{tabular}


lower number of treatments in the second year enabled the yearly working time, and consequentially the yearly LPG consumption, to be reduced by about $50 \%$ in both high and low frequency flaming (table 4). Yearly working time for chemical herbicide management was the same each year $\left(0.012 \mathrm{~h} \mathrm{~m}^{-2}\right)$ (table 4$)$.

The total cost for flaming was $1.19 € \mathrm{~m}^{-2}$ in high frequency the first year and $0.61 € \mathrm{~m}^{-2}$ the second year; $0.72 € \mathrm{~m}^{-2}$ in low frequency the first year and $0.38 € \mathrm{~m}^{-2}$ the second year (table 4).

The total cost for chemical management was $1.54 € \mathrm{~m}^{-2}$ each year. Considering that low frequency flaming was more economical than high frequency and chemical treatment and maintained the threshold level of weed cover under $10 \%$ (as opposed to chemical herbicide), our approach appears to be more sustainable from both an economic and environmental point of view.

\section{Self-Propelled Flaming Machine}

Initial weed composition was represented mainly by Papaver rhoeas L., Festuca arundinacea Schreb., and Picris echioides L. Weed cover before treatments was about $35 \%$.

Eleven treatments were carried out in both years. The threshold level of weed cover in flaming plots was maintained under 5\% throughout the experimental period and the mean percentage weed cover for the two-year period was $0.7 \%$ (table 5); at the end of the trial all weeds had been completely controlled ( $0 \%$ of weed cover). There were statistical differences in percentage weed cover due to the different machines used for weed management. The percentage mean weed cover over two years was about $5 \%$ for mowing but with peaks of $10 \%$ to $15 \%$ before mowing (table 5) and at the end of the experiment weed composition consisted of Festuca arundinacea and Papaver rhoeas. The untreated control presented a percentage mean weed cover of $77 \%$.

The self-propelled machine had shorter working times than those necessary for controlling weeds with the manual lance. Yearly working time for flaming was $0.010 \mathrm{~h} \mathrm{~m}^{-2}$ the first year and $0.008 \mathrm{~h} \mathrm{~m}^{-2}$ the second year (table 5). Yearly working time for mowing was $0.014 \mathrm{~h} \mathrm{~m}^{-2}$ each year, higher than flaming and insufficient to reach the same level of weed control (table 5).

The LPG consumption for a single treatment, with LPG working pressure of $0.2 \mathrm{MPa}$, was on average $0.010 \mathrm{~kg} \mathrm{~m}^{-2}$. The yearly LPG consumption was $0.136 \mathrm{~kg} \mathrm{~m}^{-2}$ the first year and $0.110 \mathrm{~kg} \mathrm{~m}^{-2}$ the second year (table 5). The lower LPG consumption in the second year was a consequence of the shorter working times due to the lower weed cover.
The total cost for mowing (yearly costs for mowing plus blowing and collecting cut weeds and transport to the dump) was $1.19 € \mathrm{~m}^{-2}$ each year. Yearly flaming was more economical than mowing and was $0.52 € \mathrm{~m}^{-2}$ the first year, and $0.41 € \mathrm{~m}^{-2}$ the second year (table 5).

\section{Mounted Flaming MaChine}

Initial weed composition was represented mainly by Trifolium spp., graminaceous species, Ranunculus spp., Veronica persica Poir., and Picris echioides L. Weed cover before treatments was about $60 \%$. The eight flaming treatments performed, maintained the threshold level of weed cover under $20 \%$ throughout the whole experimental period, with a mean of $13 \%$ weed cover (table 6). Mowing never reduced the percentage weed cover under $30 \%$, which was on average about $45 \%$ (table 6). The untreated control was constantly above the of $60 \%$ threshold.

Final weed composition with flaming was represented mainly by graminaceous species whereas in the other plots in addition to graminaceous species, Ranunculus spp., Trifolium spp. and Picris echioides L. persisted, confirming that flaming treatments are more effective on broadleaf species compared to grass.

Ulloa et al. (2010) tested flaming on five broadleaf species (Convolvulus arvensis L., Kochia scoparia L., Ipomea hederacea Jacq., Abutilon theophrasti Medik. and Hibiscus trionum L.) and one grass (Echinochloa crus-galli L.) and noted that the broadleaf species could be controlled (90\% dry matter reduction) with a propane dose ranging from 30 to $60 \mathrm{~kg} \mathrm{ha}^{-1}$ when flamed at vegetative growth stages (three to four leaves). The grass Echinochloa crusgalli needed $40 \mathrm{~kg} \mathrm{ha}^{-1}$ to obtain an $80 \%$ dry matter reduction at the vegetative stage, and $130 \mathrm{~kg} \mathrm{ha}^{-1}$ to obtain a $90 \%$ dry matter reduction at the flowering stage.

In our experiment a mean LPG dose of $66 \mathrm{~kg} \mathrm{ha}^{-1}$ repeated eight times was not sufficient to completely control graminaceous species, however it maintained a lower percentage weed cover compared to mowing, confirming the effectiveness of flaming. The yearly LPG consumption, with an LPG working pressure of $0.25 \mathrm{MPa}$,

Table 6. Mean weed cover and yearly number of treatments, LPG consumption, working time and total cost for different weed control systems on the graveled cycle way during the trial in 2011.

\begin{tabular}{lccc}
\hline & $\begin{array}{c}\text { Mounted } \\
\text { Flaming } \\
\text { Machine }\end{array}$ & $\begin{array}{c}\text { Mounted } \\
\text { Mowing } \\
\text { Shredder }\end{array}$ & Control \\
\hline Yearly number of treatments & 8 & 4 & 0 \\
Weed cover mean $(\%)$ & $13.3 \mathrm{c}$ & $44.3 \mathrm{~b}$ & $63.3 \mathrm{a}$ \\
Yearly LPG consumption $\left(\mathrm{kg} \mathrm{ha}^{-1}\right)$ & 531.63 & - & - \\
Yearly working time $\left(\mathrm{h} \mathrm{ha}^{-1}\right)$ & 29.06 & 7.96 & \\
Yearly total cost per use $\left(€ \mathrm{ha}^{-1}\right)$ & 2300 & 370 & \\
\hline
\end{tabular}

Table 5. Mean weed cover and yearly number of treatments, LPG consumption, working time and total cost for different weed control systems on cement pavement of railway station during the two years of trial (from May 2009 to May 2011).

\begin{tabular}{|c|c|c|c|c|c|}
\hline & \multicolumn{2}{|c|}{$\begin{array}{c}\text { Flaming } \\
\text { Self-Propelled Flaming Machine }\end{array}$} & \multicolumn{2}{|c|}{$\begin{array}{c}\text { Mowing } \\
\text { String Trimmer }\end{array}$} & \multirow{2}{*}{ Control } \\
\hline & First Year & Second Year & First Year & Second Year & \\
\hline Yearly number of treatments & 11 & 11 & 2 & 2 & 0 \\
\hline Weed cover mean $(\%)$ & \multicolumn{2}{|c|}{$0.7 \mathrm{c}$} & \multicolumn{2}{|c|}{$4.8 \mathrm{~b}$} & $77.4 \mathrm{a}$ \\
\hline Yearly LPG consumption $\left(\mathrm{kg} \mathrm{m}^{-2}\right)$ & 0.136 & 0.110 & - & - & \\
\hline Yearly working time $\left(\mathrm{h} \mathrm{m}^{-2}\right)$ & 0.010 & 0.008 & 0.014 & 0.014 & \\
\hline Yearly total cost per use $\left(€ \mathrm{~m}^{-2}\right)$ & 0.52 & 0.41 & 1.19 & 1.19 & \\
\hline
\end{tabular}


was $532 \mathrm{~kg} \mathrm{ha}^{-1}$ (table 6). The working time decreased significantly from the first to the eighth treatment (from 7.02 to $1.40 \mathrm{~h} \mathrm{ha}^{-1}$ ) as a consequence of the reduced need to control the percentage weed cover. The first flaming treatment required an LPG consumption of $128 \mathrm{~kg} \mathrm{ha}^{-1}$, the eighth was performed with $26 \mathrm{~kg} \mathrm{ha}^{-1}$. The yearly working time for mowing was $7.96 \mathrm{~h} \mathrm{ha}^{-1}$ (table 6). The total cost for flaming was $2300 € \mathrm{ha}^{-1}$ (table 6).

Ulloa et al. (2011) used a custom-built flaming machine at a constant speed of $6.4 \mathrm{~km} \mathrm{~h}^{-1}$ equipped with four "LT2x8 Liquid Torch" (Flame Engineering, 2007) with costs of $16.80 \$ \mathrm{ha}^{-1}$ for a single flaming operation in the United States, without taking into account the costs of the equipment and labor; e.g. the current price of propane in the United States $\left(0.28 \$ \mathrm{~kg}^{-1}\right)$ was multiplied by a recommended usage dose of $60 \mathrm{~kg} \mathrm{ha}^{-1}$. Considering that in our experiment the mean LPG consumption for a single treatment was $66 \mathrm{~kg} \mathrm{ha}^{-1}$, if we had used the same method as Ulloa et al. (2011) to calculate the costs, the result would be $140 € \mathrm{ha}^{-1}$ instead of the $289 € \mathrm{ha}^{-1}$, the actual cost for a single treatment. The total cost for mowing was $370 € \mathrm{ha}^{-1}$. Considering the big difference between the two methods in terms of costs, in this kind of context, flaming works best if applied using an integrated approach. A combination of the two methods would probably give the best results in terms of costs and effectiveness (weed cover reduction). In other words, flaming, which was more effective, could be applied in the middle of the cycle way where it is too difficult to mow too close to the soil because of the presence of the gravel and where usually a higher weed control level is required. Unlike with mowing, flaming controls the weeds that grow on the soil surface or whose vegetation is very close to the soil (for example, flat stoloniferous weeds or weeds forming flat rosettes). The sides of the cycle way could be mowed, where the weed control threshold is usually higher and weeds are usually quite high when removed.

\section{CONCLUSION}

Flaming could be a good and environmental friendly alternative to herbicide application in urban and suburban areas. This is particularly relevant today as citizens are more and more sensitive to these aspects and aware of environmental pollution and the related health problems. In fact agrochemical and herbicide applications are more dangerous in urban areas than in farms especially because of the higher presence of people.

The aim of this research was to develop and test different kinds of flaming machines suitable for urban and sub-urban contexts. Our four different machines (backpack flamer, trolley, self-propelled, and mounted machines) enabled flaming to be performed in a wide range of contexts, from a stone wall to a suburban cycle way, from a line of trees in an avenue to a railway station. Flaming can be performed on different kinds of hard surfaces, such as cement, gravel, stone, soil, etc.

This technique was compared to the usual weed management strategies (mowing or herbicide application) adopted by the local authorities where the trials were run. In all the urban contexts, flaming gave better results in terms of weed control and similar or better results in terms of costs. In addition, there was generally a reduction in labor time and costs from the first to the second year of experiment since the first year acts as a transition from the previous to the new management. Although in the trials run in a graveled cycle way (sub-urban area) mowing had lower total costs, flaming was more effective on weeds. Thus, mowing and flaming could be integrated for managing the central section of the cycle way, as flaming works well on gravel and can also treat flat weeds.

More efficient burners would improve our machines, for example using special inlets on the carter of the burners, in order to guarantee a secondary air flow to improve the efficiency of the combustion. Precision agriculture technologies could also be utilized in order to maximize the efficiency of the thermal treatment. For example, a smart flaming machine which in urban areas would only work where there are weeds, using the information acquired by a perception system (for example a digital camera connected to a specific unit for image analysis).

\section{ACKNOWLEDGEMENTS}

The authors greatly acknowledged the funding supported by the "Fondazione Cassa di Risparmio di Pisa", the Municipality of Livorno (Italy), the Municipality of San Giuliano Terme (Pisa, Italy) and the Tuscany Region (PorCREO call project). The authors are also grateful to Roberta del Sarto and Calogero Plaia (Department of Agriculture Food and Environment, University of Pisa) and Marco Ginanni, Silvano Toniolo, Alessandro Pannocchia, Giovanni Melai, Claudio Marchi, Luciano Pulga and Paolo Gronchi (Centro di Ricerche Agro-Ambientali "Enrico Avanzi," University of Pisa) for their contributions in these trials and to the development of the machines.

\section{REFERENCES}

Ascard, J. 1995. Thermal weed control by flaming: Biological and Technical Aspects. Alnarp: SLU Reprocentralen.

Biondi, P. 1999. Chapter 21: Gestione delle macchine agricole. In Meccanica agraria. Le macchine agricole, 547-571. Torino, Italy: UTET. (In Italian)

Ellwanger, T. C., S. W. Bingham, and W. E. Chapell. 1973a. Physiological effects of ultra-high temperatures on Corn. Weed Sci. 21(4): 296-299.

Ellwanger, T.C., S. W. Bingham, W. E. Chapell, and S. A. Tolin.1973b. Cytological effects of ultra-high temperatures on Corn. Weed Sci. 21(4): 299-303.

Flame Engineering. 2007. Red Dragon Liquid Torches. LaCrosse, Kan.: Flame Engineering Inc. Available at: http://www. flameengineering.com/Liquid Burners.html. Accessed 01 February 2013.

F.R.I.M.A.T., 2012. Tariffario delle lavorazioni meccanico-agricole della Toscana (Italy). [(In Italian)

Hansen, P. K., P. Kristoffersen, and K. Kristensen. 2004. Strategies for non-chemical weed control on public paved areas in Denmark. Pest Manag Sci. 60(6): 600-604. 
Holmøy, R., and K. Storeheier. 1995. Flaming: fundamental knowledge and pratical use in selective weed control. In Proceedings of the $9^{\text {th }}$ European Weed Research Society International Symposium on Challenges for Weed Science in a Changing Europe, 14-15. Budapest, Hungary. EWRS Publisher, Wageningen, The Netherlands.

Hunt, D. 2001. Chapter 4: Costs. In Farm Power and Machinery Management, 75-77. Long Grave, Ill.: Waveland Press.

Knezevic, S. Z., C. M. Costa, S. M. Ulloa, and A. Datta. 2009. Response of corn (Zea mays L.) types to broadcast flaming. In Proceedings of the $8^{\text {th }}$ European Weed Research Society Workshop on Physical and Cultural Weed Control, 92-97. Zaragoza, Spain. D. C. Cloutier Editor, Weed Science Institute, Québec, Canada. Available at: http://www.ewrs.org/pwc.

Kristoffersen, P., A. M. Rask, and S. U. Larsen. 2008. Non-chemical weed control on traffic islands: A comparison of the efficacy of five weed control techniques. Weed Res. 48(2): 124-130.

Lazzari, M., and F. Mazzetto. 2005. Chapter 3: Analisi economiche delle macchine agricole. In Prontuario di Meccanica Agraria e Meccanizzazione, 62-79. Torino, Italy: Reda Edizioni (In Italian)

MAITO, 2013. Available at: http://www.maito.it/index.php?option= com virtuemart\&page $=$ shop.browse \& category id $=7 \&$ Itemid $=5$ $3 \&$ vmcchk $=1 \&$ Itemid $=53$. Accessed 01 February 2013.

OJ. 2009. Directive 2009/128/EC of the European Parliament and of the Council of 21 October, establishing a framework for Community action to achieve the sustainable use of pesticides. Official Journal of the European Union, 71-86. L 309 $24 / 11 / 2009$
Parish, S. 1990. The flame treatment of weed seedlings under controlled conditions. In Crop Protection in Organic and Low Input Agriculture, BCPC Mono, 193-196. Farnham, Surrey, U.K.: British Crop Protection Council

Peruzzi, A., L. Lulli, M. Fontanelli, C. Frasconi, M. Ginanni, M. Raffaelli, and F. Sorelli. 2010. Innovative strategies for physical weed control oh hard surfaces in urban area in Central Italy: development of new flaming operative machines. In Book of Abstracts of the XVII ${ }^{\text {th }}$ World Congress of the International Commission of Agricultural Engineering (CIGR), 263.Québec City, Canada. P. Savoie, J. Villeneuve and R. Morisette, eds. Québec, Canada: Agriculture and Agri-Food, Soils and Crops Research and Development Centre. Available at: http://www. csbe-scgab.ca.

Rask, A. M., and P. Kristoffersen. 2007. A review of non-chemical weed control on hard surfaces. Weed Res. 47(5): 370-380.

Rask, A. M., P. Kristoffersen, and C. Andersen. 2012. Controlling grass weeds on hard surfaces: effect of time intervals between flame treatments. Weed Technol. 26(1): 83-88.

Ulloa, S. M., A. Datta, and S. Z. Knezevi. 2010. Tolerance of selected weed species to broadcast flaming at different growth stages. Crop Prot. 29(12): 1381-1388.

Ulloa, S. M., A. Datta, C. Brueningb, B. Neilsonb, J. Millerb, G. Gogosb, and S. Z. Knezevic. 2011. Maize response to broadcast flaming at different growth stages: Effects on growth, yield and yield components. Eur. J. Agron. 34(1): 10-19. 